33. Mortensen PB. Gregersen N 1982 The biological origin of ketotic dicarboxylic aciduria: II. In vivo and in vitro investigations of the $\beta$-oxidation of $\mathrm{C}_{8}-\mathrm{C}_{16^{-}}$ dicarboxylic acids. Biochem Biophys Acta 710:477-484

34. Thomas JA. Darby TD. Wallin RF, Garvin PJ, Martis L 1978 A review of the biological effects of di-(2-ethylhexyl)phthalate. Toxicol Appl Pharmacol 45:1-27

35. Turnbull D. Rodricks JV 1985 Assessment of possible carcinogenic risk to humans resulting from exposure to di(2-ethylhexyl)phthalate (DEHP). J Am
Coll Toxicol $4 \cdot 111-145$

36. Horie $\mathrm{S}$, Suga T 1985 Enhancement of peroxisomal $\beta$-oxidation in the liver of rats and mice treated with valproic acid. Biochem Pharmacol 34:1357-1362

37. Partin JC 1974 Liver ultrastructure in Reye's syndrome. In: Pollack JD (ed) Reye's Syndrome I. Grune and Stratton, New York, pp 117-129

38. Partin JC, Bove K, Partin JS, Schubert WK 1978 Liver and muscle ultrastructure in Reye's syndrome. In: Crocker JFS (ed) Reye's Syndrome II. Grune and Stratton, New York, pp 217-236

\title{
Announcements
}

\author{
Annual Meeting
}

The American Pediatric Society and the Society for Pediatric Research announce the abstract deadline for the 1987 Annual Meeting (April 27-May 1, Disneyland Hotel, Anaheim, CA) has been set as December 3, 1986.

For further information contact: SPR - Debbie L. Wogenrich, The Society for Pediatric Research, Department of Pediatrics, UNM School of Medicine, Albuquerque, NM 87131 (505)277-6629 or APS-Dr. Audrey K. Brown, Secretary-Treasurer, Department of Pediatrics, Box 49, SUNY, Health Sciences Center at Brooklyn, 450 Clarkson Avenue, Brooklyn, NY 11203, (718)2701692.

\section{Announcement of Prize Competition for 1987 and 1988}

The Central Association of Swiss Milk Producers, West-strasse 10, CH-3000 Bern 6, announces the competition for the International Award for Modern Nutrition which it is donating for 1987 as well as 1988 . The award amounts to SFr. 20’000.- and will be awarded to a scientist from a member state of the International Dairy Federation*.

Topic for 1987: Importance of the Trace-Elements $\mathrm{Zn}, \mathrm{Se}$ and $\mathrm{Cr}$ in Nutrition-Deadline: February 15, 1987.

Topic for 1988: Nutrition and Sport-Deadline: February 15, 1988.

Authors of scientific articles dealing with the topic in question are invited to submit the following documents in triplicate: curriculum vitae; bibliography; reprints of the most relevant articles related to the award-topic, which have been published during the past 5 yr.

The documents should be written in English, French or German and sent to the President of the jury, Prof. Dr. med. Ettore Rossi, Medizinische Universitäts-Kinderklinik, Inselspital, CH-3010 Bern/Switzerland.

* Member states are: America, Algeria, Austria, Australia, Belgium, Canada, Chile, Czechoslovakia, Denmark, Finland, France, Greece, W. Germany, Hungary, India, Italy, Iraq, Ireland, Israel, Japan, Kenya, Luxemburg, Malta, Netherlands, Norway, New Zealand, Poland, Spain, Sweden, South Africa, Switzerland, United Kingdom, USSR.

\section{Scientific Meeting}

The Society for Behavioral Pediatrics will hold its 5th Annual Scientific Meeting in Anaheim, CA on April 26-27, 1987 in conjunction with the SPR/APS/APA meetings at the Disneyland Hotel. For further information and registration forms, please contact Ms. Noreen Spota at (215) 248-9168 or Dr. Candace Erickson at (212) 305-9862. 